\title{
LITERASI MEDIA BAGI KAUM IBU DI RPTRA DHARMA SUCI
}

\author{
Virgitta Septyana* \\ Program Studi Ilmu Komunikasi, Universitas BundaMulia
}

\begin{abstract}
The digital era is carrying information and can be accessed anyone through smartphone in the hands. Hoax is one of the big problem which is often divisive among community. Hence, the importance of media literation for residents so as to have the ability apply thought critical of the mass media and doing so can raise awareness and responsibiloties as citizens.

This society's empowerment activity involving the writer takes place at RPTRA Dharma Suci. The reason choosing women is to become a gate keeper who will filter the news for the children. With the collaboration between presentation and study case, women are expected to distinguish the right information or not.
\end{abstract}

\section{Keywords: Media Literation, News, Gate Keeper}

\begin{abstract}
ABSTRAK
Era digital membawa arus informasi yang deras dan bisa diakses siapa saja melalui gawai di tangan masing-masing.Konten berita bohong atau yang dikenal dengan hoax sudah menjadi salah satu permasalahan besar yang kerap kali dapat memecahbelahkan masyarakat. Oleh karena itu, pentingnya literasi media bagi para warga agar memiliki kemampuan mengaplikasikan pemikiran kritis terhadap media massa dengan cara demikian dapat membangun kesadaran dan tanggungjawab sebagai warga negara.

Pada kegiatan 'Pemberdayaan kepada Masyarakat' (PKM) yang melibatkan penulis, pelatihan Literasi Media mengambil tempat di RPTRA Dharma Suci. Alasan menyasar para kaum Ibu tak terlepas bahwa merekalah yang pada akhirnya menjadi gate keeper, yang akan menyaring tayangan yang akan ditonton oleh anak mereka. Dengan mengkolaborasikan antara presentasi dan contoh kasus, diharapkan para Ibu mampu memilah informasi yang benar dan tidak.
\end{abstract}

\section{Kata Kunci: Literasi Media, Berita, Gate Keeper}

\footnotetext{
*email: vseptyana@bundamulia.ac.id
} 


\section{PENDAHULUAN}

Era digital membawa arus informasi yang deras dan bisa diakses siapa saja melalui gawai di tangan masing-masing. Berita dan isu terus berdatangan dan berdesakan untuk bisa mendapatkan perhatian publik. Persoalan politik, sosial, ekonomi seringkali dibungkus dengan isu-isu sensitif, seperti suku, agama, ras, dan antar golongan (SARA) sehingga memunculkan konten berita bohong. Konten berita bohong atau yang dikenal dengan hoax sudah menjadi salah satu permasalahan besar yang kerap kali dapat memecahbelahkan masyarakat. Berdasarkan data dari Gatra online, saluran terbanyak penyebar berita bohong dijumpai di media sosial sebesar 92.40 $\%$. Peringkat selanjutnya diduduki oleh aplikasi percakapan yaitu $62,80 \%$ lalu situs web sebesar $34,90 \%$. Sementara itu, untuk televisi hanya $8,70 \%$, media cetak $5 \%$, email $3,10 \%$ dan terakhir radio yaitu $1.20 \%$.

Untuk meningkatkan pemahaman masyarakat mengenai pentingnya keamanan data, maka perlu dilakukan literasi media sosial, yang berguna untuk memahami bagaimana bermedia sosial yang baik. Tak hanya itu saja, namun kemampuan bernalar menjadi salah satu hal yang penting dalam mencerna konten berita yang disuguhkan. Lemahnya budaya literasi membentuk masyarakat yang kurang mampu bernalar. Lemahnya kemampuan bernalar akan membuat seseorang sulit berpikir jernih dan kritis dalam memandang setiap persoalan, sehingga yang muncul adalah emosi dan egoisme. Alhasil, isu-isu provokatif dan hasutan yang dihembuskan berita-berita hoax akan dengan mudah diterima dan disebarkan sehingga dapat menyulut konflik di tengah masyarakat.

Kemampuan bernalar merupakan bekal penting di era digital yang dibanjiri informasi seperti sekarang. Nalar yang sehat akan membuat seseorang bisa berpikir kritis dan berusaha obyektif dalam menilai segala sesuatu, termasuk dalam memandang suatu isu atau berita. Nalar yang sehat akan membentengi seseorang dari prasangka, kebencian, emosi, dan egoisme yang bisa memengaruhi pemikirannya dalam menilai suatu persoalan.

Oleh karena itu, literasi media penting untuk diberikan kepada para kaum Ibu agar lebih bijak lagi dalam mencerna dan memilah berita-berita sehingga tidak terhasut dengan konten berita yang sifatnya hoax. Target pelatihan kegiatan PKM kali ini menyasar peserta para kaum Ibu yang berada dalam wilayah RPTRA Dharma Suci. RPTRA Dharma Suci merupakan salah satu RPTRA yang dirancang sebagai bagian dari program Kota Layak Anak oleh Pemprov DKI Jakarta. RPTRA yang dibangun pada 2015 ini terletak di kawasan RW. 016 Kelurahan Pejagalan Kecamatan Penjaringan Kotamadya Jakarta Utara. RPTRA ini terletak didekat kolong tol Jembatan Tiga - pintu masuk tol Jembatan Tiga. Secara geografis, lokasi RPTRA ini terletak diantara kawasan RW 016 dan RW 018 Kelurahan Pejagalan.

\section{Identifikasi Masalah}

Jaman sekarang media massa sudah sangat mendominasi kehidupan kita. Media massa adalah media yang digunakan untuk menyampaikan informasi kepada khalayak melalui media elektronik dan media cetak, bisa berupa hiburan ataupun pendidikan, berfungsi juga untuk memberikan opini atau pendapat. Media literasi muncul karena media massa dianggap telah mengabaikan fungsi mendidik dari media. Media literasi dikenal dengan istilah "melek media" di Indonesia. Media saat ini sudah kurang memperhatikan etika dan nilai profesionalisme media, bagaimana media sudah menjadi kendaraan politik dan ideologi tertentu, bagaimana realitas mampu dipelintir oleh media, sehingga masyarakat pada dasarnya memerlukan apa yang disebut sebagai literasi media, agar mereka aktif, cerdas, peka dan kritis dalam mengamati fenomena pemberitaan media saat ini

Pada kegiatan PKM kali ini, sasaran peserta adalah ibu-ibu yang berada dalam 
wilayah RPTRA Dharma Suci. Melek terhadap konten yang disiarkan oleh media menjadi hal yang penting bagi para Ibu-ibu. Hal ini tak terlepas bahwa merekalah yang pada akhirnya menjadi gate keeper, yang akan menyaring tayangan yang akan ditonton oleh anak mereka.

\section{Maksud dan Tujuan Kegiatan}

Adapun maksud dan tujuan diselenggarakan PKM ini adalah untuk :

- Meningkatkan pemahaman tentang media massa

- Meningkatkan kemampuan berpikir kritis

- Memiliki kemampuan melakukan proses belajar partisipatif $\square$

- Menguasai pengetahuan melek media

\section{Pengertian Literasi Media}

Kemampuan memahami teks media secara sederhana disebut sebagai literasi media. Menurut Tamburaka (2013) literasi media berasal dari bahasa Inggris yaitu Media Literacy terdiri dari kata yakni media adalah tempat pertukaran pesan dan literacy berarti melek, kemudian dikenal dalam istilah Literasi Media yang mana melek dapat diartikan pada kemampuan khalayak terhadap media dan pesan media massa dalam kontek komunikasi massa.

Hal senada juga disampaikan oleh Baran dan Dennis (2010) yang mengatakan bahwa literasi media sebagai suatu rangkaian kegiatan melek media yaitu gerakan melek media dirancang untuk meningkatkan kontrol individu terhadap media yang mereka gunakan untuk mengirim dan menerima pesan. Kemudian dalam hal ini melek media dipandang sebagai sebuah keterampilan yang bisa berkembang di dalam sebuah rangkaian dimana kita tidak selalu melek terhadap media dalam semua situasi, setiap waktu serta terhadap semua media.

Literasi media lebih tertarik menciptakan kemampuan warga untuk mengakses, menganalisa, mengevaluasi, dan sampai pada memproduksi informasi untuk hasil-hasil yang spesifik. Literasi media juga berarti kemampuan mengaplikasikan pemikiran kritis terhadap media massa dengan cara demikian dapat membangun kesadaran dan tanggungjawab sebagai warga negara (Turrow dalam Wahid dan Pratomo, 2017).

\section{Kecakapan Literasi Media}

Menurut Potter (2004) setelah seseorang melakukan kegiatan literasi media maka diharapkan ia akan memiliki setidaknya tujuh kecakapan yaitu:

\section{Analysis}

Yaitu berkaitan dengan kemampuan memahami isi dan konten serta membongkar dan mengkaji suatu pesan atau informasi dari sebuah media. Sehingga dalam tahap kemampuan ini kita diharapkan menjadi pribadi yang paham atas suatu pesan yang tersampaikan dari sebuah media sampai kepada tahapan pendapat kita atas suatu informasi tersebut.

\section{Evaluation}

Dalam tahapan evaluasi ini kita diharapkan untuk mampu memberikan penilaian atas suatu pesan informasi yang media sampaikan. Lebih dari itu pada tahapan ini kita diharapkan mampu menilai baik dan buruk, serta benar tidak benar dari sebuah pesan informasi yang disampaikan oleh media.

\section{Grouping}

Dalam tahapan ini kita diharapkan untuk mampu mengelompokan berbagai informasi yang kita peroleh dari suatu media dalam sebuah persamaan dan perbedaan tertentu. Baik kesamaan dan perbedaan topik maupun lebih jauh kepada persamaan dan berbedaan sudut pandang atas suatu isu, topik, ataupun permasalahan tertentu. 


\section{METODE PENELITIAN}

Kegiatan PKM kali ini memadukan antara pemberian materi serta memberikan contoh kasus terkait pemberitaan media terhadap satu isu tertentu. Selama 120 menit, 5 narasumber saling berkolaborasi untuk menyampaikan materi terkait literasi media. Hal ini penting disampaikan mengingat peserta kali ini adalah para Ibu yang mempunyai tanggungjawab untuk mengontrol sang anak dalam memanfaatkan perkembangan teknologi di bidang media saat ini.

Acara PKM kali ini diawali dengan sesi pertama tentang "Paham Radikalisme dalam Media". Pada sesi ini, narasumber menjelaskan tentang bagaimana media saat ini digunakan sebagai salah satu alat untuk menyebarkan paham radikalisme. Dalam sesi ini, narasumber juga memberikan data-data serta website yang disalahgunakan demi kepentingan kaum ekstrimist. Setelah itu, barulah sesi kedua dimulai dengan penyampaian materi terkait Kekerasan dalam Media Televisi. Topik pada sesi kedua dirasa penting disampaikan mengingat para ibu yang hadir memiliki anak yang terpapar terhadap media.

\section{HASIL DAN PEMBAHASAN}

Kegiatan PKM di RPTRA Dharma Suci, dilaksanakan pada 24 Juli 2017 yang dimulai pukul 09:00-12.00 WIB. Peserta berkumpul di ruang serba guna RPTRA Dharma Suci yang berjumlah 30 orang ibu-ibu disekitar RPTRA Dharma Suci.

Acara diawali dengan sesi pertama tentang "Paham Radikalisme dalam Media". Pada sesi ini, narasumber menjelaskan secara garis besar, bagaimana saat ini media sosial berperan dalam kehidupan manusia. Selain itu, disampaikan pula tentang dampak positif dan negatif dari perkembangan teknologi. Sesi tersebut lalu dilanjutkan dengan penyampaian bagaimana paham radikalisme mulai merasuki media. Pada sesi ini, narasumber juga menyampaikan beberapa website yang digunakan untuk menginformasikan bagaimana cara merakit bom sehingga tak heran jika saat ini berkembang gerakan- gerakan yang dianggap radikal dan mengancam keutuhan negara. Setelah sesi pertama usai, acara dilanjutkan dengan memberikan games kepada Ibu-ibu yang hadir seputar materi yang dibawakan oleh narasumber.

Setelah melakukan games, maka topik berikutnya dilanjutkan dengan durasi selama 60 menit tentang Kekerasan dalam Media Televisi. Hal ini penting disampaikan mengingat para ibu yang hadir memiliki anak yang terpapar terhadap media. Beberapa dari para Ibu juga menyampaikan keluhannya bagaimana ketergantungan anak-anak mereka pada tayangan televisi. Tak sedikit pula tayangan yang mereka tonton menampilkan kekerasan yang tidak selayaknya ditonton bagi mereka di usia anak-anak. Untuk itulah peranan orang tua dibutuhkan untuk mendampingi dan memilah tayangan yang layak ditonton bagi anak-anak. Pada sesi ini, tanya-jawab terjadi di antara peserta dan narasumber. Para Ibu yang hadir menyampaikan keresahan yang mereka rasakan akan pengaruh televisi di dalam kehidupan anak mereka. Hal ini juga tak lepas dari peran lingkungan yang membuat para anak semakin tergantung dan tak bisa lepas dari media televisi.

Dari kegiatan PKM kali ini, dapat disimpulkan bahwa literasi media sangat penting bagi para Ibu. Hal ini bukan hanya untuk diri Ibu itu sendiri, namun hal ini berpengaruh dalam mereka mendidik anak mereka. Tumbuh kembang seorang anak tentunya dimulai dari lingkungan terdekat mereka, yaitu keluarga. Jika Para Ibu tidak dapat memilah dan memahami media mana yang memberikan dampak negatif bagi anaknya, maka hal ini pula yang pada akhirnya dapat merusak generasi muda bangsa.

\section{SIMPULAN}

Secara umum, antusias peserta yang sangat tinggi. Peserta sangat proaktif untuk menaggapi kasus-kasus terkini akibat konten berita bohong yang tersebar. 
Tak sedikit pula dari para Ibu yang akhirnya berbagi kisah dalam mengontrol saluran informasi bagi anaknya.

Kegiatan ditutup dengan pemberian sertifikat dari pihak sekolah kepada pembicara dan foto bersama seluruh peserta.

\section{DAFTAR PUSTAKA}

Potter, W.J. 2004. Theory of Media Literacy : A Cognitive Approach. California: Sage Publications.

Stanley J. Baran, Dennis K.Davis. 2010. Mass Communication Theory: Foundations, Ferment and Future. Belmot: CA, Wadswoth

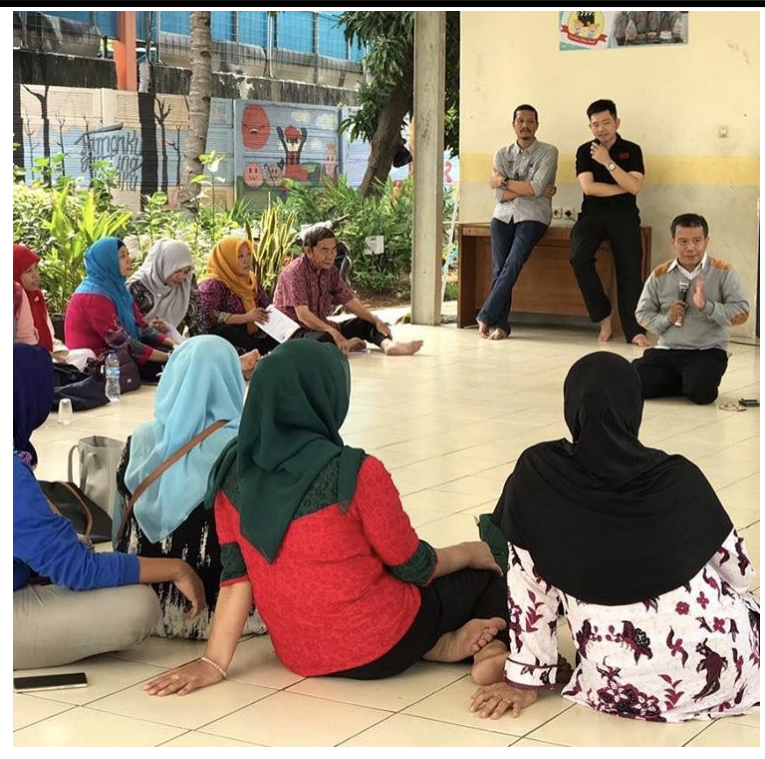

Gambar 1: Sesi pemberian materi

Tamburaka, Apriadi. 2013. Literasi Media: Cerdas Bermedia Khalayak Media Massa. Jakarta: Raja Grafindo Persada.

Wahid, Abdul dan Pratomo, Dhinar. 2017. Masyarakat dan Teks Media. Malang: UB Press

https://www.gatra.com/rubrik/nasional/pemer intahan-pusat/307668-persentase-hoaxterbanyak-hadir-dari-media-sosial

http://riaupos.co/3237-spesial-hoax-danpentingnya-literasi-media-.html

Berikut dokumentasi kegiatan PKM.

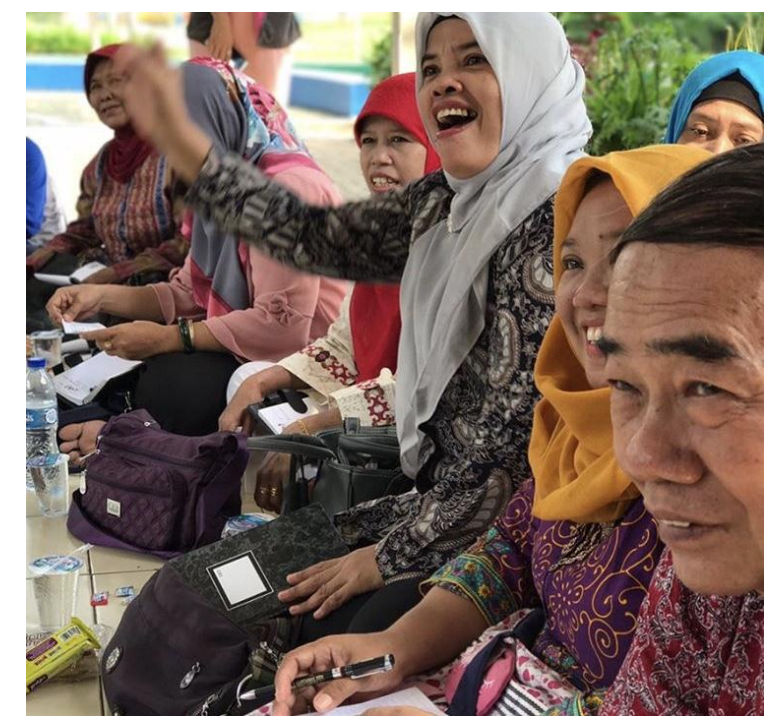

Gambar 2: Sesi tanya-jawab 